\title{
THE ROLE OF SCAFFOLDING IN THE DECONSTRUCTING OF THINKING STRUCTURE: A CASE STUDY OF PSEUDO-THINKING PROCESS
}

\author{
Imam Kusmaryono*, Nila Ubaidah, Mochamad Abdul Basir \\ Universitas Islam Sultan Agung, Indonesia
}

\begin{tabular}{|c|c|}
\hline Article Info & ABSTRACT \\
\hline Article history: & \multirow{6}{*}{$\begin{array}{l}\text { This study aimed to (1) analyze the role of scaffolding in deconstructing } \\
\text { pseudo-thinking structure, and (2) analyze the development of students' } \\
\text { thinking structures after receiving scaffolding. The study was framed with a } \\
\text { qualitative methodology by involving case study design. This research was } \\
\text { conducted at State Junior High School } 31 \text { in Semarang City, Indonesia. Data } \\
\text { was collected through tests, observation, and interview methods. Result of the } \\
\text { study indicated that (1) scaffolding has changed the pseudo thinking process } \\
\text { into a real thought process, and ( } 2 \text { ) scaffolding could develop students' } \\
\text { thinking structure into a more complex (abstract) level. Their thinking } \\
\text { structure was initially on the stage of comparative thinking structure before } \\
\text { receiving scaffolding assistance and after receiving scaffolding, to developed } \\
\text { into the stage of logical reasoning thinking structure. In other words, } \\
\text { scaffolding could become a useful strategy to help students go through } \\
\text { different Zone of Proximal Development (ZPD). }\end{array}$} \\
\hline Received Jun 17, 2020 & \\
\hline Revised Sep 21, 2020 & \\
\hline Accepted Sep 22, 2020 & \\
\hline Keywords: & \\
\hline $\begin{array}{l}\text { Pseudo Thinking, } \\
\text { Scaffolding, } \\
\text { Thinking Structure, } \\
\text { Zone of Proximal Development }\end{array}$ & \\
\hline
\end{tabular}

\section{Corresponding Author:}

Imam Kusmaryono,

Departement of Mathematics Education,

Universitas Islam Sultan Agung,

Jl. Kaligawe Raya Km. 4, Semarang, Center Java 50112, Indonesia.

Email: kusmaryono@unissula.ac.id

\section{How to Cite:}

Kusmaryono, I., Ubaidah, N., \& Basir, M. A. (2020). The role of scaffolding in the deconstruction of thinking structure: A case study of pseudo-thinking process. Infinity, 9(2), 247-262.

\section{INTRODUCTION}

Develop students' ability in problem-solving is one of the teacher's roles (Keiler, 2018; Simamora, Saragih, \& Hasratuddin, 2018). In problem-solving, the procedure of mathematics problem solving is a cognitive process based on what had been known (Ekawati, Kohar, Imah, Amin, \& Fiangga, 2019; Samsonovich, Kitsantas, O’Brien, \& De Jong, 2015). In this case, students should use cognitive strategy to determine how they learn, reprocess information, to use what had been learned. They must think to obtain a suitable problem-solving strategy, so they could achieve the cognitive purpose, that is, to solve problems (Evans \& Swan, 2014; Novita, Widada, \& Haji, 2018; Susanti, 2018).

Students in the activity of thinking to solve mathematical problems can occur the possibility of answers obtained is true or false. Incorrect answers are not necessarily caused 
by thinking processes that are also wrong (Herna, Nusantara, Subanji, \& Mulyati, 2016; Subanji \& Nusantara, 2016). This wrong answer does not mean that the subject (student) cannot solve it. When students solve problems, they often give "false" answers relatively quickly, spontaneously, and do not check or reflect the results of their work. This happens because of the low ability to think reflective in solving problems, so their thought processes tend to produce wrong answers (Choy, Yim, \& Tan, 2017; Deringöl, 2019). This process of thinking is still "raw" rather than the actual thought process so that the process of pseudo thinking occurs (Herna et al., 2016).

The pseudo-thinking process is a thinking process in which students thought as if they had solved a problem, but they just imitated what the teacher or someone else did (Subanji \& Nusantara, 2016; Vinner, 1997). The students did not understand what they just did. They often provide answers spontaneously without any check or control on the thinking process (Thanheiser, 2010; Vinner,1997).

Pseudo-thinking process has become interesting as students experienced it "unreal", just a pseudo-thinking. The pseudo-thinking process could be discovered in two forms i.e., (1) the answer is correct, but the student could not justify it. This is called as "true" pseudo (Caglayan \& Olive, 2010; Herna et al., 2016; Thanheiser, 2010) and (2) the answer is incorrect, but the student actually could solve it well. This is called as "false" pseudo (Subanji, 2013; Vinner, 1997). Both pseudo-thinking processes could be fixed after being reflected with or without scaffolding (Wibawa, Nusantara, Subanji, \& Parta, 2018).

This pseudo-thinking process could still be fixed as it is not the real thinking process as incapability. Furthermore, through the reflection process, the teacher should believe that the students actually have the potentials to develop with assistance from teachers and or more capable peers.

According to Vygotsky, each student had the Zone of Proximal Development (ZPD), usually mentioned as a distance between actual development level and higher potential development level. Vygotsky suggested that students could achieve maximal area if they received enough assistance. If students learned without assistance, they would still be in the actual area and could not develop to higher potential development level (Chairani, 2015).

Given that the pseudo thinking process is not a real thought process, it can still be improved through the process of reflection. At the time of reflection, the teacher provides scaffolding with the aim of improving students' thinking structures. The improvement of this thinking structure is based on the belief that when students are in the Zone of Proximal Development (ZPD), they have the potential to develop optimally.

Cognitive Structure is a basic mental process used by an individual to understand information (Garner, 2007). Then it was also called a mental structure, or thinking pattern (Kusumadewi, Kusmaryono, Jamallullail, \& Saputro, 2019). A students thinking pattern would develop based on the cognitive development stage (Mascolo, 2015). However, some students met obstacles in cognitive development, so that it is the time for the student to get assistance to face learning barriers. After the scaffolding was given, the student's cognitive structure became more developed and more complex. Scaffolding was learning assistance provided by teachers to students who had barriers to learning. The learning would be more effective if teachers helped students to develop cognitive structures that would equip them for individual learning (Kusumadewi et al., 2019).

This research focuses on two objectives. The first objective is to analyze the role of scaffolding in deconstructing pseudo-thinking structures. The second objective is to analyze the development of students' thinking structures after receiving scaffolding. 


\section{METHOD}

\subsection{Research Design}

This research was conducted in qualitative methodology by involving case study design. This research was conducted at State Junior High School 31 in Semarang City, Indonesia. Setting of the study involved kind of naturalistic investigation because the scaffolding was studied on natural situation without manipulating any variables (Kalu \& Bwalya, 2017).

\subsection{Participants}

This study involved 36 students in grade 8 , a teacher, and a supervisor. The students had attended mathematics learnings with a group investigation approach and attended problem-solving test. Based on the test results, students whose scores did not reach the specified criteria and had the most error answers, it is reasonable to suspect that these students experienced a pseudo thinking process, then considered as data sources. Researchers act as supervisors of learning in the classroom. Where as the instructor is a senior teacher who has more than 10 years of teaching experience in school.

\subsection{Instruments}

The data collection method included tests, observation, and interviews. The instruments used in this study were written test questions and a list of interview questions. The interaction in scaffolding between students and teachers is observed by supervisors during the mathematics learning process. The deep interview was conducted on students by purposive snowball technique in order to collect complete information. An instrument of the written test was a test of problem-solving as follows.

Problem: A water storage tank had 10 meters length, 5 meters in width, and 4 meters in height. The tank is full of water and will be distributed to 40 houses. Each house receives 500 liters of water every day. If the tank is empty, the company will refill it again until it is full.

Question: How many times does the company should refill the water storage tank in one month to fulfill the need of water for 40 houses?

\subsection{Procedure}

The subject of the study was focused on students who were in the lower group, namely students who received low test scores or did not reach the minimum completeness criteria of 70.0. The study was conducted by tracking the response of students' answers in solving problems. Then so that students can correct their mistakes students are given the opportunity to reflect with the help of scaffolding.

The author conducted this research by exploring the response of student answers in solving problems. Then, in order to correct the mistakes, the students are given a chance to do reflection with scaffolding assistance. Scaffolding is carried out through the steps: (1) giving questions; (2) problems to solve for students; (3) asking students to express what they knew; (4) giving a chance for students to review their work; (5) asking students to describe the plan of problem-solving; (6) asking students to combine their ideas; (7) asking students to share with others; (8) giving question and keywords to students; (9) if the students need further information, teachers guide them to go back to step 4, dan restart until it is finished 
(Buli, Basizew, \& Abdisa, 2017; San Martín, 2018; Van de Pol, Volman, \& Beishuizen, 2010).

\subsection{Data Analysis, and Validation}

This research is natural, researchers as data collection tools (human instruments). The data is analyzed inductively and is a descriptive one. Data analysis was described as an interactive cycle through stages of data collection, data reduction, data display, and drawing conclusions (Miles \& Huberman, 2016; Moleong, 2007). To ensure data validity, the authors used the triangulation of theory and data source (Moleong, 2007).

\section{RESULTS AND DISCUSSION}

\subsection{Results}

After students complete formative tests at the end of learning, all student answers are analyzed and presented in Table 1.

Table 1. Description of the test score statistics for each group

\begin{tabular}{ccccc}
\hline \multirow{2}{*}{ Group } & \multirow{2}{*}{ Students } & \multicolumn{3}{c}{ Test Score } \\
\cline { 3 - 5 } & & Range & Mean & Std. Deviation \\
\hline Top & 10 & $95-100$ & 98.5 & 2.415 \\
Middle & 17 & $70-90$ & 74.4 & 11.023 \\
Bottom & 9 & $40-65$ & 45.6 & 5.270 \\
Total & 36 & & & \\
\hline
\end{tabular}

Based on the data in Table 1, there were 9 students in the lower group whose test scores did not reach the minimal completeness criteria of 70.0. So that the students' answers were analyzed for errors, and the following results were obtained (see Table 2).

Table 2. Error analysis of student answers

\begin{tabular}{ccc}
\hline No. & Subject & Analysis of student answers \\
\hline 1 & $(\mathrm{~S} .01)$ & incorrect concept \\
2 & $(\mathrm{~S} .05)$ & incorrect concept \\
3 & $(\mathrm{~S} .17)$ & incorrect concept \\
4 & $(\mathrm{~S} .18)$ & incorrect concept \\
5 & $(\mathrm{~S} .20)$ & incorrect concept \\
6 & $(\mathrm{~S} .22)$ & incorrect concept \\
7 & $(\mathrm{~S} .06)$ & incorrect analysis \\
8 & $(\mathrm{~S} .29)$ & incorrect analysis \\
9 & $(\mathrm{~S} .31)$ & incorrect analysis \\
\hline
\end{tabular}

The following is the result of students' answer response to represent 2 cases happened i.e., the case of incorrect concept (S.01) and incorrect analysis (S.06). Student (S.01) was 
supposed to experience a "false" pseudo-thinking process, and the student (S.06) was supposed to experience a "true" pseudo-thinking process.

Student's answer response to mathematics problem that was tested in this research was taken as a sample to discuss in Figure 1.

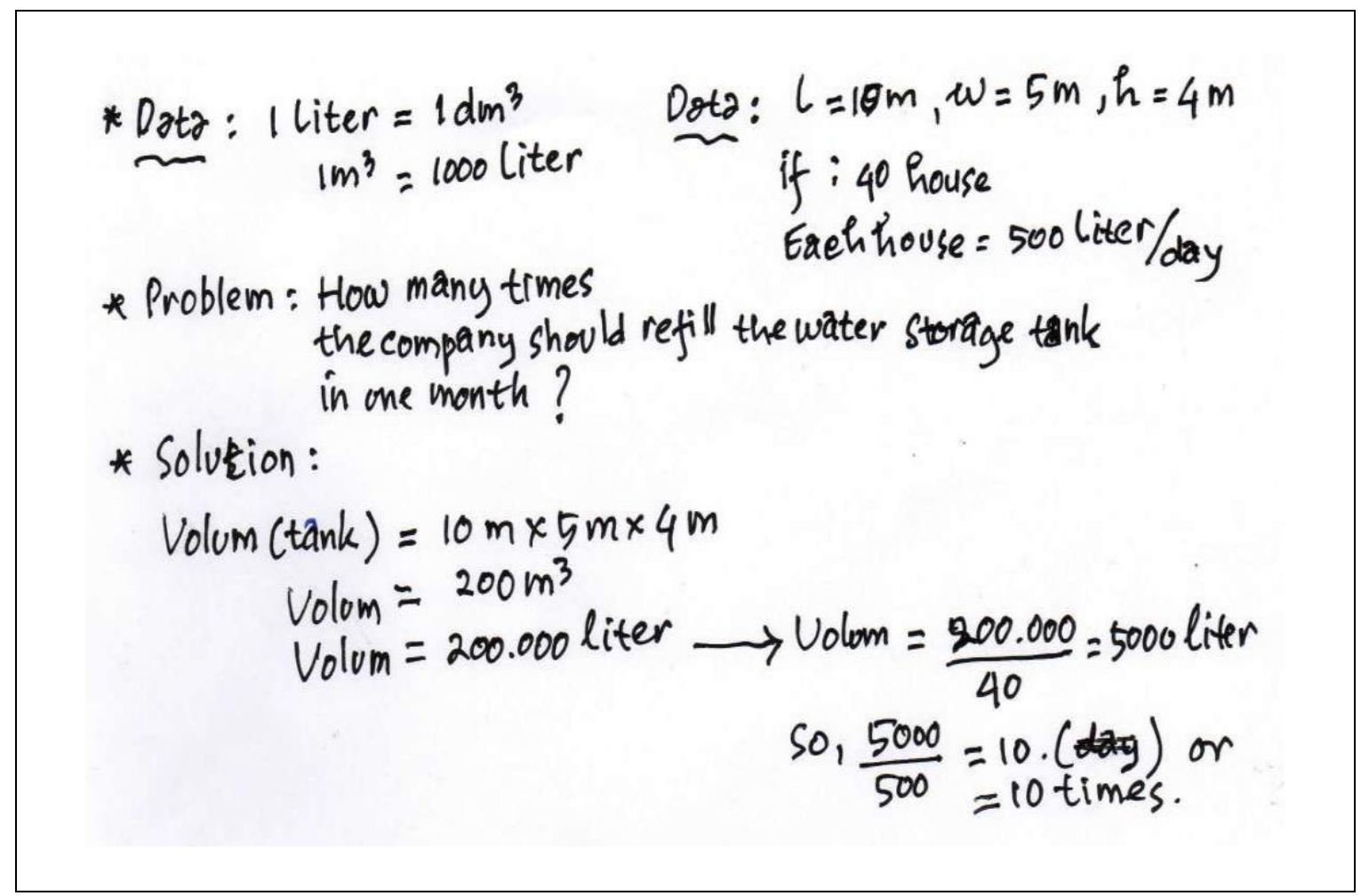

Figure 1. Student answer (S.01) before reflection

Considering the student answer (S.01) in Figure 1, finally, it was found that the company should refill the tank 10 times a month. The answers given by students are not right. To find out the student's thought process when solving a problem, the researcher conducted the interview as follows.

Researcher : Why did you write down 1 liter $=1 \mathrm{dm}^{3}$, and $1 \mathrm{~m}^{3}=1000$ liter?

Subject (S.01) : I have been thinking that I would convert the volume of the cube in liter measurement.

Researcher : Did you understand how to solve question number 1?

Subject (S.01) : I do, and I have some ideas to do.

Researcher : Was your answer saying that the company should refill the tank 10 times a month, correct?

Subject (S.01) : I can not explain, but I hope it is correct.

Researcher : The calculation you made had not finished yet. It still had to be continued to the next step.

Subject (S.01) : Oh, I see. (the subject looked disappointed).

Researcher : Did you conduct a recheck?

Subject (S.01) : I did not recheck it. 
Based on students' answers in the interview passage indicated that students experience pseudo thinking processes. This pseudo thinking process occurs because the answers are spontaneous, and students do not check their work in the form of reflection. The structure of student thinking (S.01) in solving problems before reflection (see Figure 2).

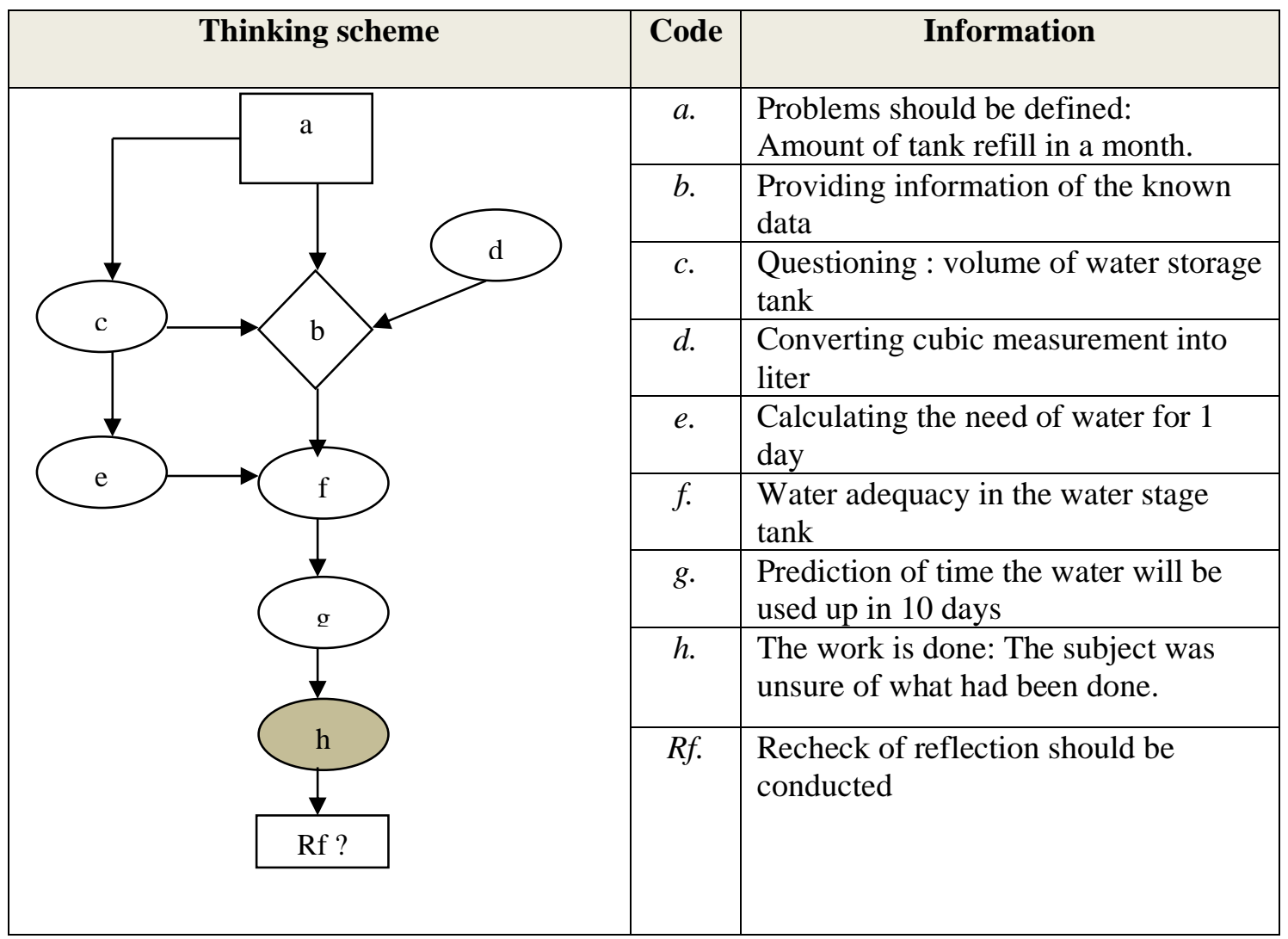

Figure 2. The structure of student thinking (S.01) before reflection

Based on the student (S.01) thinking structure as displayed in Figure 2, it could be said that the student was on a comparative thinking structure. It is basic to learn and as a requirement for other more complex cognitive structures (Garner, 2007). Student mathematical ability on this level was processing information by identifying how the data were similar or different, including recognition, memorization, constant conservation, classification, spatial orientation, temporal orientation, and metaphoric thinking. Thinking structure on this stage could still be developed with scaffolding assistance from the teacher. The scaffolding was given to the students to reflect on what had been done and direct their initial knowledge to solve the problems they faced (Maharani \& Subanji, 2018).

The role of the teacher in learning as resource persons and facilitators who provide assistance as needed (scaffolding) in order to facilitate the construction process of knowledge that is built by students. At a certain level of cognition, teachers provide scaffolding assistance by guiding them or providing key instructions, cues, questions, and justifications so that students will be easier to move or develop into higher thought processes.

To correct the mistakes, the students were given a chance to do a reflection. They rechecked the steps of problem-solving. While students were having difficulties, the teacher gave the scaffolding. The work of students after reflection with the help of scaffolding is shown in Figure 3. 


\section{Revision:}

Water needs 1 day $=40 \times 500$ liter $=20.000$ liter

water needs 1 month $=20.000$ liter. $\times 30=600.000$ lifer.

\$o, volum $(\tan k) \cdot N=$ water needs 1 month. $200.000 \cdot N=600.000$

$N=\frac{600.000}{200.000}$

$\therefore$ So, in imonth water tant must be filled 3 times.

Figure 3. Student answer (S.01) after reflection

To understand the student (S.01) thinking structure, consider the following interview between the researcher and the student.

Researcher : Please check whether the result you obtained had answered the question?

Subject (S.01) : I had rechecked and I found that my answer did not solve to the problem questioned.

Researcher : Was there any mistake you did while working on it?

Subject (S.01) : I did a mistake.

Researcher : In which part did you find the mistake?

Subject (S.01) : The answer should not be 10. I would recheck it.

To help the student, the scaffolding was implemented through words to track or keywords. By the keywords, the student could find the solution.

Researcher : Please calculate the need for water in a month.

Subject (S.01) : The need for water in a month is 500 liters x 40 x $30=600.000$ liters.

Researcher : Then, make an equation (relation) with the volume of the water tank.

Subject (S.01) : The volume of the water tank as 200,000 liters will be used up in 10 days (1-time refill). So, in a month should be 600.000 liters divided by 200.000 liters equals to 3 or (3 times refill).

Researcher : Have you found your answer? 
Subject (S.01) : The answer is 3 times a refill in a month.

Researcher : What conclusion did you obtain?

Subject (S.01) : The need for water for 40 houses in a month equals to 3 times of water tank volume.

Researcher : Are you sure? How do you prove it?

Subject (S.01) : I'm sure it's correct.

Subject (S..01) : (Volume of water tank $) \times($ amount of water refill $)=$ need of water in a month. It was $(10 \mathrm{~m} \times 5 \mathrm{~m} \mathrm{x} 4 \mathrm{~m}) \times 3=40 \times 500$ liters $\times 30$. Obtained $600 \mathrm{~m}^{3}=6.000$ liter.

Based on the result of the student's work and the interview, the following is the thinking structure after reflection (see Figure 4).

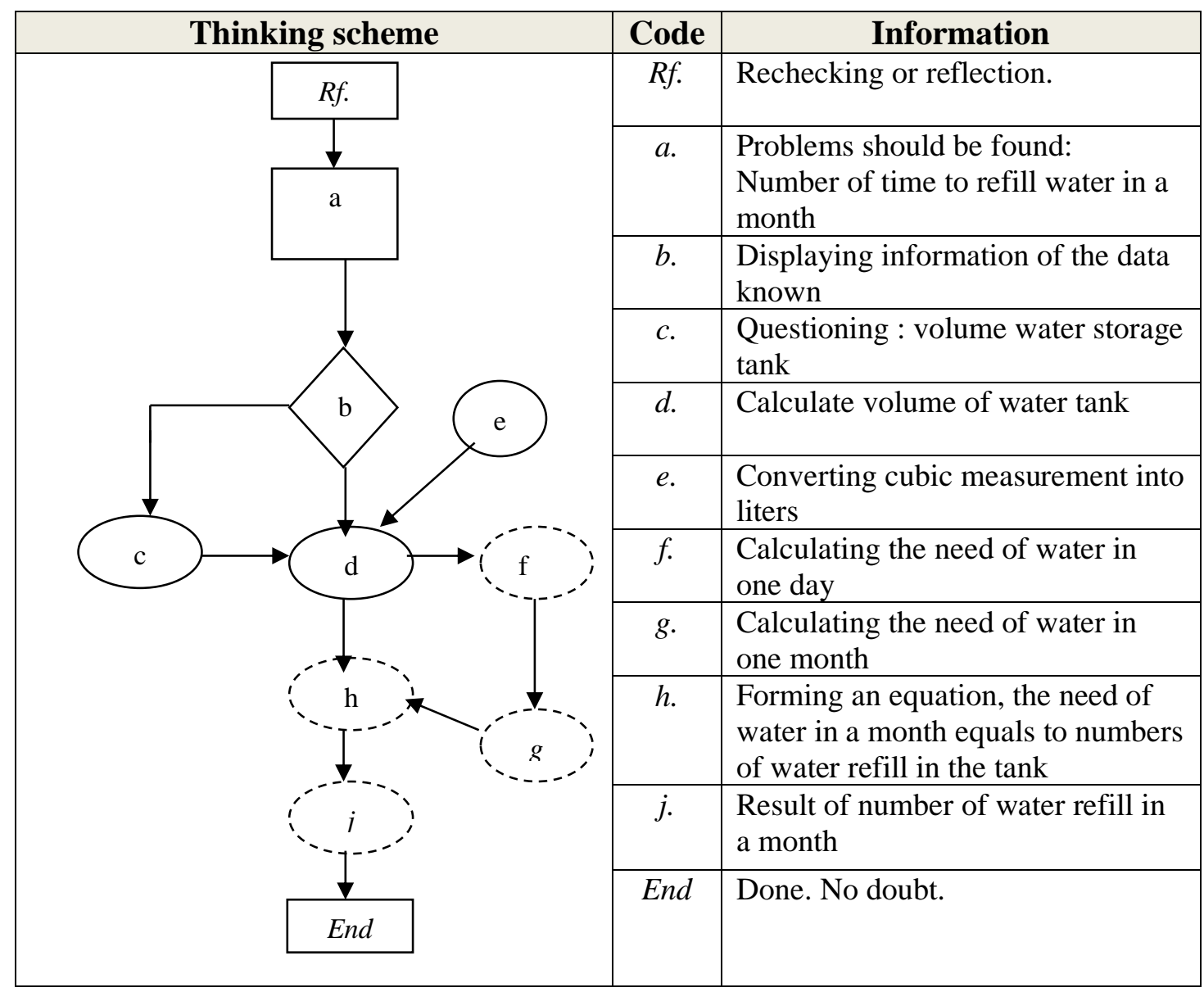

Figure 4. The structure of student thinking (S.01) after reflection

The response of student answer (S.06) on mathematics questions tested in this research was chosen as sample to discuss and present in Figure 5. 


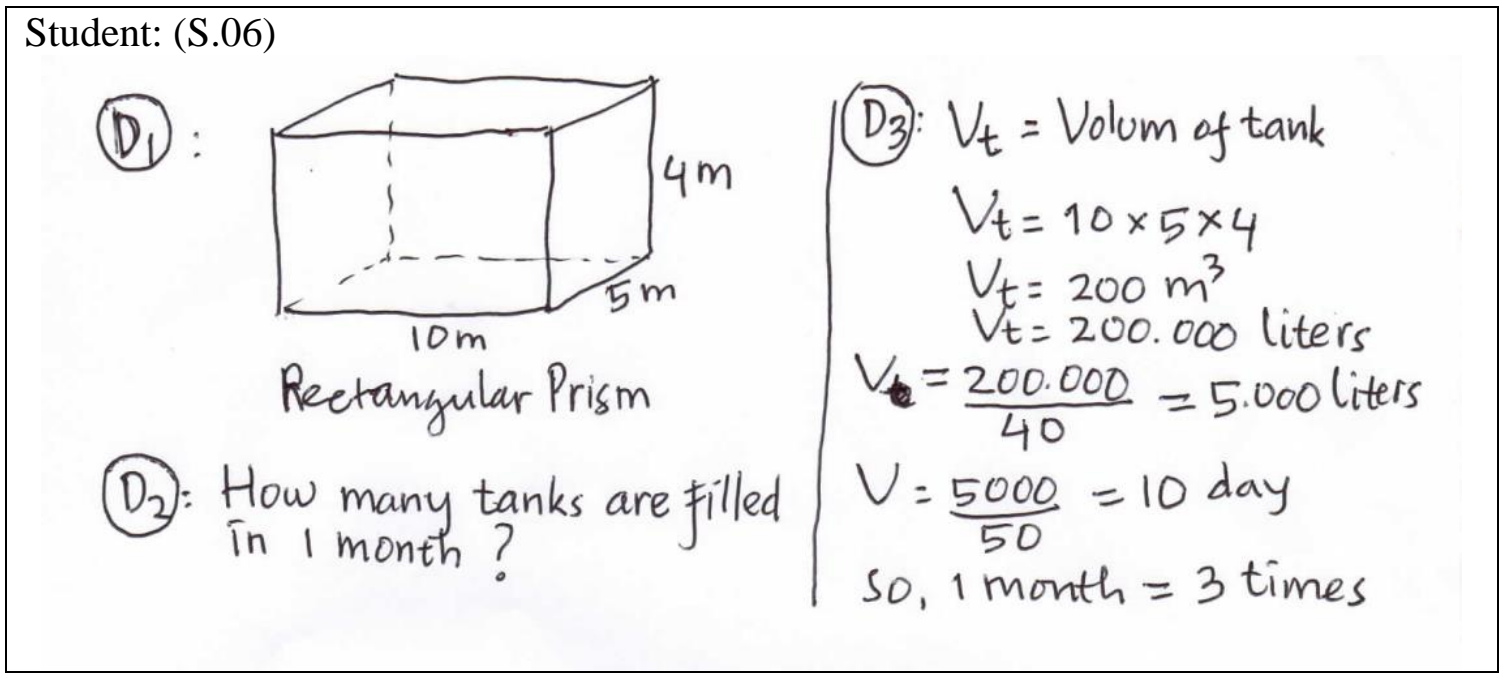

Figure 5. Student answer (S.06) before reflection

Based on the result of the analysis on the student (S.06) response answer, it indicated that the final result was correct. However, there were some solving steps missing that were not written by the student (S.06). Furthermore, an interview was conducted to determine how student's (S.06) thinking process was, as presented below.

Researcher

Subject (S.06)

Researcher

Subject (S.06)

Researcher

Subject (S.06)

Researcher

Subject (S.06)
: What is the conclusion (answer) of this problem?

: The company should fill the water tank 3 times a month.

: Are you sure about your answer?

: Probably.

: Did you re-check it?

: I did not.

: Could you prove that your answer is correct?

: Sorry, I have no idea. I could not explain it.

The student's thinking structure (S.06) could be described in the following scheme (see Figure 6). 


\begin{tabular}{|l|c|l|}
\hline \multicolumn{1}{|c|}{ Code } & \multicolumn{1}{|c|}{ Information } \\
\hline$a$. & $\begin{array}{l}\text { Problems should be defined: } \\
\text { Amount of tank refill in a month. }\end{array}$ \\
\cline { 2 - 3 } & $\begin{array}{l}\text { Providing information of the } \\
\text { known data }\end{array}$ \\
\hline $\begin{array}{l}\text { Question: lots of water needed for } \\
\text { a month. }\end{array}$
\end{tabular}

Figure 6. The structure of student thinking (S.06) before reflection

After that, the student (S.06) got a chance to do reflection in order to correct the answer with scaffolding assistance from teacher, through the following steps.

Researcher

Subject (S.06)

Researcher

Subject (S.06)

Researcher

Subject (S.06)

Researcher

Subject (S.06)
: Calculate the need for water in a month!

: Need of water $=40 \times 500$ liters $\times 30=600.000$ liters

: What is the volume of the water tank?

: Volume of water tank $=10 \mathrm{~m} \times 5 \mathrm{~m} \mathrm{x} 4 \mathrm{~m}=200 \mathrm{~m}^{3}=$ 200.000 liters.

: Explain the correlation between the need for water and the volume of the water tank!

: The need for water in a month should be equal to the volume of water in the tank.

: Create the equation for the correlation of both variables!

: $\quad($ Volume of the tank) $\mathrm{x}$ (Number of water refill $)=$ Need of water in a month.

$(10 \mathrm{~m} \times 5 \mathrm{~m} \times 4 \mathrm{~m}) \times \mathrm{k}=40 \times 500 \times 30$.

200.000 liters $\mathrm{x} \mathrm{k}=600.000$ liters.

$\mathrm{k}=600.000: 200.000$

$\mathrm{k}=3$ 


$\begin{array}{lll}\text { Researcher } & : & \text { What is your conclusion? } \\ \text { Subject (S.06) } & : & \text { The number of water refill into the tank is } 3 \text { times } \\ \text { Researcher } & : & \text { Please re-check your answer! } \\ \text { Subject (S.06) } & : & \text { (Volume of the tank) } \times \text { (Number of water refill) } \\ & \text { water in a month. } \\ & (10 \mathrm{~m} \times 5 \mathrm{~m} \times 4 \mathrm{~m}) \times 3=40 \times 500 \text { liters } \times 30 \\ & 600 \mathrm{~m}^{3}=600.000 \text { liters. Yes, the result is similar. } \\ \text { Researcher } & : \text { Are you sure? } \\ \text { Subject (S.06) } & : \text { Pretty sure. }\end{array}$

The following is a student's (S.06) answer response after the reflection process with scaffolding assistance as presented in Figure 7.

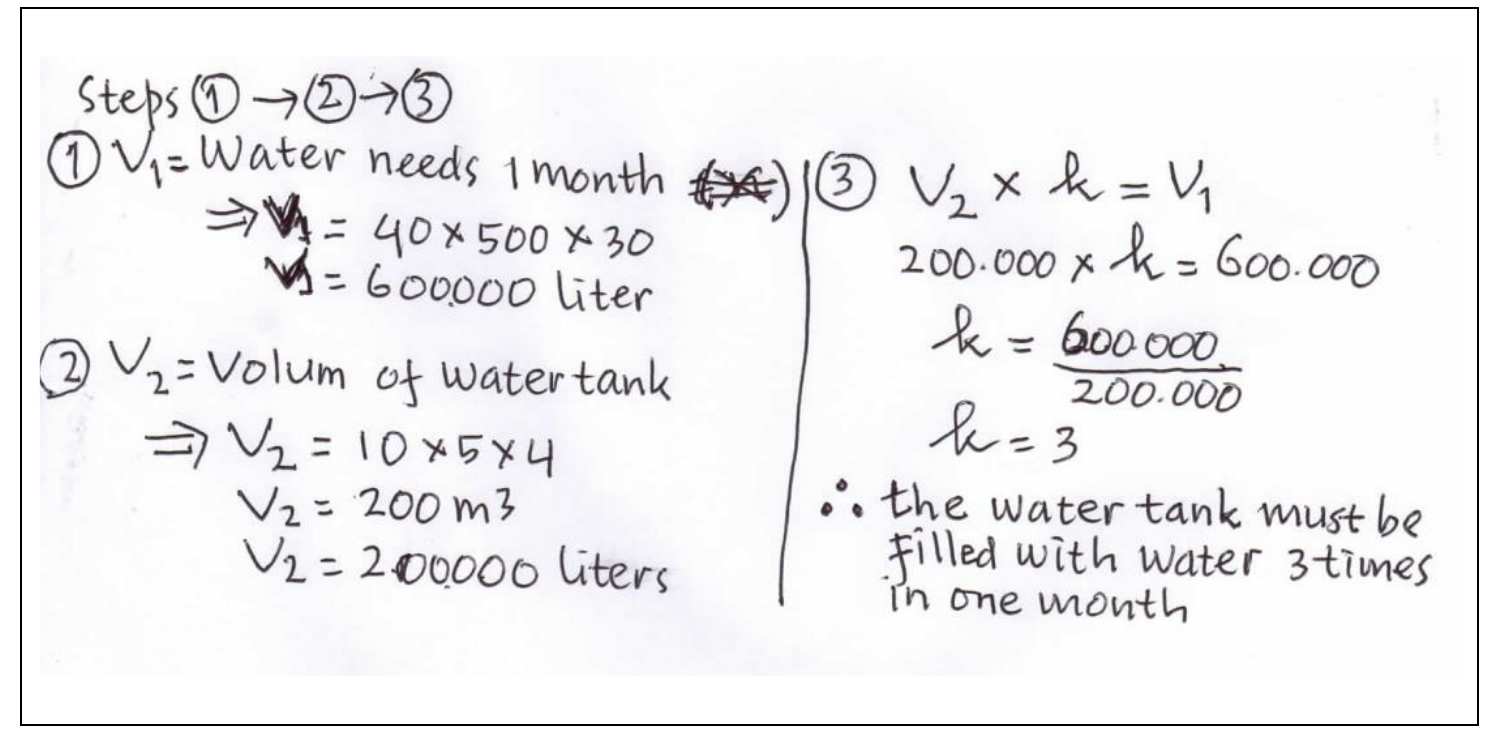

Figure 7. Student answer (S.06) after reflection

After reflection with scaffolding, the student could find the solution and provide an explanation for the answer obtained correctly. Through scaffolding, the student (S.06) could fix the thinking structure as presented in Figure 8. 


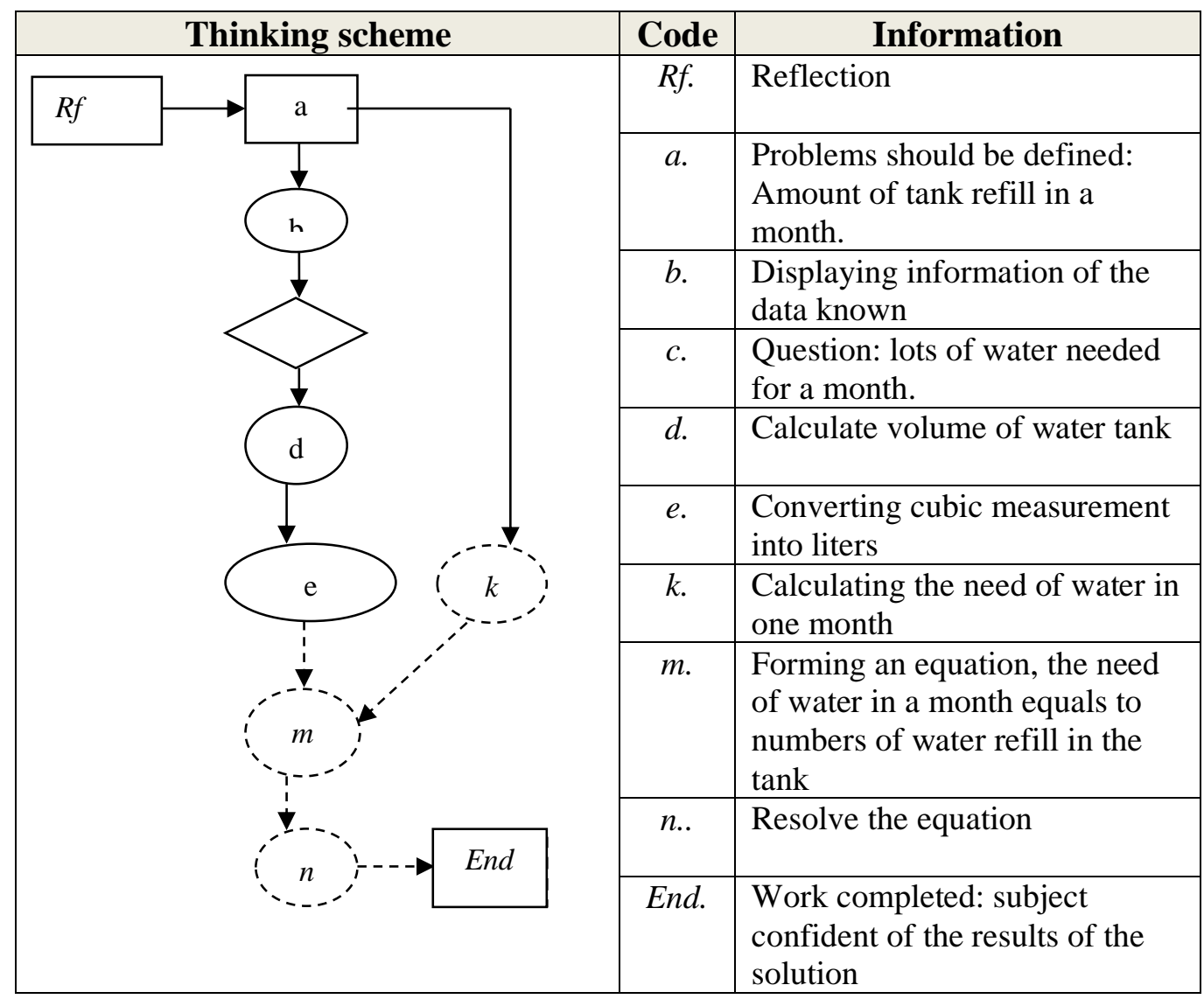

Figure 8. The structure of student thinking (S.06) after reflection

\subsection{Discussion}

\subsubsection{Before scaffolding}

Considering the result of analysis on students' answer responses (S.01 and S.06) and interview toward the students on how they solved mathematics problems, it could be said that the students experienced a pseudo-thinking process before the reflection process. The student (S.01) experienced a "false" pseudo-thinking process, while the student (S.06) experienced a "true" pseudo-thinking process.

Based on the interview, the student (S.01) was detected to have a "false" pseudothinking process. The student did not understand what he has done. The concept of problemsolving was not complete yet. The solution obtained did not receive treatment of re-checking, but it had been considered as a conclusion, so the answer was incorrect. Specifically, the student (S.01) was said to experience the so-called "pseudo-conceptual" thinking process, as the main process focused on the inappropriate concept, reasoning, correlation between concepts, and implementation (Vinner, 1997).

The student's answer (S.06) in the interview was a manifestation of "true" pseudothinking process behavior (Caglayan \& Olive, 2010; Herna et al., 2016; Thanheiser, 2010). Although the answer was correct, the student (S.06) was unsure and could not provide explanation (proof) for the answer.

In addition, the student did not conduct reflection. According to experts, a "true" pseudo-thinking process happens when the answer provided by a student is correct, but the student (S.06) could not provide justification (Caglayan \& Olive, 2010; Herna et al., 2016; 
Thanheiser, 2010). Specifically, the student (S.06) was said to experience the so-called "pseudo-analytical" thinking process, as the main process is a problem-solving process (Vinner, 1997).

Considering the student's thinking structure (S.01) before reflection (Figure 2), it could be said that both of the students were on a comparative thinking structure. It is basic to learn and as a requirement for other more complex cognitive structures. Student's mathematical ability on this level is to process information by identifying how data is similar or different. It includes recognition, memorization, constant conservation, classification, spatial orientation, temporal orientation, and metaphorical thinking. On the other hand, a student's thinking structure (S.06) before reflection (Figure 6) was on a symbolic representation thinking structure. The symbolic representation structure changes information into a coding system that could be accepted in general (culture) including verbal and nonverbal language; mathematics; graphics (2-dimension figures, painting, logo); construction; simulation and multimedia (Garner, 2007).

Both comparative and symbolic representation thinking structures could still be developed to construct more complex mathematics knowledge structures with scaffolding assistance from the teacher. The role of the teacher is to provide assistance (scaffolding) as needed in order to ease the process of knowledge construction that is built by students themselves (Hmelo-Silver, 2004; Darling-Hammond et al., 2019).

\subsubsection{After scaffolding}

Scaffolding describes processes to support students for (Puntambekar \& Hubscher, 2005; Van de Pol et al., 2010). Scaffolding is given to students in order to reflect the learning outcome and direct the initial knowledge in solving problems (Maharani \& Subanji, 2018). Learning would be more effective if the teacher helps students (to provide scaffolding) to develop a cognitive structure for them to study independently (Kusumadewi et al., 2019).

After reflection with scaffolding assistance, the pseudo-thinking process never happened anymore. Students' answers after reflection indicated that they succeeded to correct mistakes and turn them into correct answers. It was in line with the interview result in which the students could provide explanations or proof for the answer with proper reason. The answers had been re-checked it's solving steps, the students became sure with no doubt, and the thinking process became true.

On certain cognition levels, teachers provide scaffolding assistance by providing students guidance, key instruction, signs, questions, and corrections, so the students could move or develop more easily into higher thinking processes (Van de Pol et al., 2010). After having scaffolding, the students succeeded to do reflection and correct the previous mistakes.

Moreover, scaffolding had developed students' thinking structure (S.01 and S.06). Before reflection, their thinking structure was on comparative and symbolic representation structure. After the reflection, the thinking structure developed into a logical reasoning structure (Figure 4 and Figure 8). On the logical reasoning structure, the students (S.01 and S.06) had used an abstract thinking strategy to systematically process and produce information. They could conduct analysis on problems, causal relation, and evaluation in problem-solving (Garner, 2007).

The provision of scaffolding to students is based on Vygotsky's theory (the zone of proximal development) has proven to be effective. That it can reach the level of potential development that students can actually do like problem-solving abilities under adult guidance or through collaboration with other more capable students.

According to Van de Pol et al. (2010), scaffolding could become a useful strategy to help students move through different ZPD. The scaffolding involved support from teachers 
to students while working on a task that can't be done alone (Van de Pol et al, 2010). However, it was a different mental process, constructing a new mental structure to adjust and model the model they have learned with an emphasis on the relationships among thinking objects (Navaneedhan \& Kamalanabhan, 2017).

The success of scaffolding in this research was because the teacher and students were in the correct place. The teacher as a facilitator had applied steps of scaffolding correctly and effectively. The teacher showed an attitude of appreciating student ideas and then directed them to a decision or choice that they needed to develop based on the basic rule. The final decision was brought back to the students to decide how they used the teachers' suggestions in redesigning their work. It leads to boost their confidence and activities to encourage them to use reasoning, communicating, and connecting ability between knowledge and experience they had before. Scaffolding concept could be used as an analytical tool to help students obtaining much more understanding in learning.

\section{CONCLUSION}

In the scaffolding process, effective learning interactions have occurred between the teacher and students, so the conclusions of this study are (1) scaffolding changes the pseudo thinking process into a real thought process, and (2) scaffolding could help develop students' thinking structures from simple ones to more complex (abstract) level. The development of students' thinking structures is at the stage of comparative thought structures before scaffolding is given, and then developed into logical reasoning thinking structures after receiving scaffolding. In other words, scaffolding can be a useful strategy to help students move through different zona of proximal development (ZPD).

\section{ACKNOWLEDGEMENTS}

Special thanks to students and teachers at State Junior School 31 Semarang, Indonesia. The head of Sultan Agung Islamic University, which provides funding to conduct research.

\section{REFERENCES}

Garner, B. K. (2007). Getting to Got It: Helping Struggling Students Learn How to Learn. Association for Supervision and Curriculum Development (ASCD).1703 North Beauregard St. Alexandria, VA 22311-1714.

Buli, Z., Basizew, S., \& Abdisa, K. (2017). Effects of Teacher's Scaffolding on Students' Reading Comprehension: Sire Secondary School Grade Nine Students in Focus. International Journal of Graduate Research and Review, 3(4), 89-95.

Caglayan, G., \& Olive, J. (2010). Eighth grade students' representations of linear equations based on a cups and tiles model. Educational Studies in Mathematics, 74(2), 143162. https://doi.org/10.1007/s10649-010-9231-z

Chairani, Z. (2015). Scaffolding dalam pembelajaran matematika 5. Math Didactic: Jurnal Pendidikan Matematika, 1(1), 39-44. https://doi.org/10.33654/math.v1i1.93

Choy, S. C., Yim, J. S. C., \& Tan, P. L. (2017). Reflective thinking among preservice teachers: A Malaysian perspective. Issues in Educational Research, 27(2), 234-251.

Darling-Hammond, L., Flook, L., Cook-Harvey, C., Barron, B., \& Osher, D. (2019). Implications for educational practice of the science of learning and development. 


$\begin{array}{lcccc}\text { Applied } & \text { Developmental } & \text { Science, } & 24(2), & 97-140 . \\ \text { https://doi.org/10.1080/10888691.2018.1537791 } & \end{array}$

Deringöl, Y. (2019). The Relationship between Reflective Thinking Skills and Academic Achievement in Mathematics in Fourth-Grade Primary School Students. International Online Journal of Education and Teaching, 6(3), 613-622.

Ekawati, R., Kohar, A. W., Imah, E. M., Amin, S. M., \& Fiangga, S. (2019). Students' cognitive processes in solving problem related to the concept of area conservation. Journal on Mathematics Education, 10(1), 21-36. https://doi.org/10.22342/jme.10.1.6339.21-36

Evans, S., \& Swan, M. (2014). Developing students' strategies for problem solving in mathematics: The role of pre-designed "Sample Student Work". Educational Designer, 2(7).

Herna, H., Nusantara, T., Subanji, \& Mulyati, S. (2016). The characterization of true pseudo construction in understanding concept of limit function. IOSR Journal of Research \& Method in Education, 6(5), 77-87.

Hmelo-Silver, C. E. (2004). Problem-based learning: What and how do students learn?. Educational psychology review, 16(3), 235-266. https://doi.org/10.1023/B:EDPR.0000034022.16470.f3

Kalu, F. A., \& Bwalya, J. C. (2017). What Makes Qualitative Research Good Research ? An Exploratory Analysis of Critical Elements. International Journal of Social Science Research, 5(2), 43-57. https://doi.org/10.5296/ijssr.v5i2.10711

Keiler, L. S. (2018). Teachers' roles and identities in student-centered classrooms. International Journal of STEM Education, 5(1). https://doi.org/10.1186/s40594-0180131-6

Kusumadewi, R. F., Kusmaryono, I., Jamallullail, I., \& Saputro, B. A. (2019). Analisis Struktur Kognitif Siswa Kelas IV Sekolah Dasar dalam Menyelesaikan Masalah Pembagian Bilangan Bulat. Journal of Medives : Journal of Mathematics Education IKIP Veteran Semarang, 3(2), 251-259. https://doi.org/10.31331/medivesveteran.v3i2.875

Maharani, I. P., \& Subanji, S. (2018). Scaffolding Based on Cognitive Conflict in Correcting the Students' Algebra Errors. International Electronic Journal of Mathematics Education, 13(2), 67-74. https://doi.org/https://doi.org/10.12973/iejme/2697

Mascolo, M. F. (2015). Neo-Piagetian Theories of Cognitive Development. In International Encyclopedia of the Social \& Behavioral Sciences (pp. 501-510). Elsevier. https://doi.org/10.1016/B978-0-08-097086-8.23097-3

Miles, M. B., \& Huberman, M. A. (2016). Analisis Data Kualitatif: Buku Sumber Tentang Metode-Metode Baru. Universitas Indonesia_UI Press (11th ed.). Jakarta: Universitas Indonesia (UI-Press).

Moleong, L. J. (2007). Metodologi penelitian kualitatif edisi revisi. Bandung: PT Remaja Rosdakarya.

Navaneedhan, C. G., \& Kamalanabhan, T. J. (2017). What Is Meant by Cognitive Structures? How Does It Influence Teaching - Learning of Psychology? IRA International Journal of Education and Multidisciplinary Studies, 7(2), 89-98. https://doi.org/10.21013/jems.v7.n2.p5 
Novita, T., Widada, W., \& Haji, S. (2018). Metakognisi siswa dalam pemecahan masalah matematika siswa SMA dalam pembelajaran matematika berorientasi etnomatematika Rejang Lebong. Jurnal Pendidikan Matematika Raflesia, 3(2), 6781.

Puntambekar, S., \& Hubscher, R. (2005). Tools for scaffolding students in a complex learning environment: What have we gained and what have we missed?. Educational psychologist, 40(1), 1-12. https://doi.org/10.1207/s15326985ep4001_1

Samsonovich, A. V., Kitsantas, A., O’Brien, E., \& De Jong, K. A. (2015). Cognitive Processes in Preparation for Problem Solving. Procedia Computer Science, 71, 235247. https://doi.org/10.1016/j.procs.2015.12.218

San Martín, M. G. (2018). Scaffolding the Learning-to-Teach Process: A Study in an EFL Teacher Education Programme in Argentina. Profile Issues in TeachersProfessional Development, 20(1), 121-134. http://dx.doi.org/10.15446/profile.v20n1.63032

Simamora, R. E., Saragih, S., \& Hasratuddin, H. (2018). Improving Students' Mathematical Problem Solving Ability and Self-Efficacy through Guided Discovery Learning in Local Culture Context. International Electronic Journal of Mathematics Education, 14(1), 61-72. https://doi.org/10.12973/iejme/3966

Subanji, S. (2013). Proses Berpikir Pseudo Siswa dalam Menyelesaikan Masalah Proporsi. J-Teqip, 4(2), 207-226.

Subanji, S., \& Nusantara, T. (2016). Thinking Process of Pseudo Construction in Mathematics Concepts. International Education Studies Journal, 9(2), 16-32. https://doi.org/10.5539/ies.v9n2p17

Susanti, V. D. (2018). Analisis kemampuan kognitif dalam pemecahan masalah berdasarkan kecerdasan logis - matematis. JMPM: Jurnal Matematika Dan Pendidikan Matematika, 3(1), 71-83.

Thanheiser, E. (2010). Investigating further preservice teachers' conceptions of multidigit whole numbers: Refining a framework. Educational Studies in Mathematics, 75(3), 241-251. https://doi.org/10.1007/s10649-010-9252-7

Van de Pol, J., Volman, M., \& Beishuizen, J. (2010). Scaffolding in teacher-student interaction: A decade of research. Educational psychology review, 22(3), 271-296. https://doi.org/10.1007/s10648-010-9127-6

Vinner, S. (1997). The pseudo-conceptual and the pseudo-analytical thought processes in mathematics learning. Educational Studies in Mathematics, 34(2), 97-129. https://doi.org/10.1023/A:1002998529016

Wibawa, K. A., Nusantara, T., Subanji, S \& Parta, I. N. (2018). Defragmentation of Student's Thinking Structures in Solving Mathematical Problems based on CRA Framework. Journal of Physics: Conf. Series, 1028(1), 012150. https://doi.org/10.1088/1742-6596/1028/1/012150 